\title{
From market failures to market opportunities: managing innovation under asymmetric information
}

\author{
Pierre Barbaroux
}

Correspondence: pierre.barbaroux@ inet.air.defense.gouv.fr

Management of Defence Organisations Research Department, French Air Force Research Center, Air Base 701, SALON Air 13661, France

\begin{abstract}
This article presents a review of the literature that focuses on the role played by information asymmetry in the management of innovation. Results are organised in two categories. On the one hand, information asymmetry is considered as a major source of market failures because it affects the quality of innovative goods and services available on the market and disturbs the process of allocating resources efficiently. On the other hand, information asymmetry is presented as a major source of market opportunities, the latter existing only because individuals do not possess the same - exhaustive and complete sets of - information. Therefore, information asymmetry plays a dual role as it both generates market failures and gives birth to entrepreneurial opportunities. Within this framework, the article discusses the main implications of managing innovation under asymmetric information.
\end{abstract}

Keywords: Information asymmetry; Entrepreneurship; Innovation

\section{Springer}

\section{Review}

Introduction

Mainstream economists consider that information asymmetry is a major source of market failures as it affects how individuals assess the quality of goods and services available on the marketplace (Akerlof 1970) and/or how individuals anticipate on others' intentions and agency (Spence 1976). When individuals are incapable of evaluating the quality of goods and services and/or are unable to observe other individuals' private information, then the market fails to produce equilibrium prices and coordinate transactions efficiently (Stiglitz 2000). Examples of economic situations involving asymmetric information include employers seeking to discover the true abilities of their future employees before recruiting them (Spence 2002) or investors trying to discover the true value of a firm before investing in or acquiring it. Interestingly, some other economists, in particular the tenants of the Austrian tradition in economics, consider that information asymmetry, far from being a source of market failures, is a condition for market opportunities to emerge. In this view, opportunities exist only because individuals do not possess substitutable information sets (either complete or incomplete) regarding market forces and technology. It follows that asymmetric information creates the conditions for entrepreneurs to search for new business opportunities, leading them to find ways to

(C) 2014 Barbaroux; licensee Springer. This is an Open Access article distributed under the terms of the Creative Commons Attribution License (http://creativecommons.org/licenses/by/2.0), which permits unrestricted use, distribution, and reproduction in any medium, provided the original work is properly cited. 
acquire 'more and more accurate and complete mutual knowledge of potential demand and supply attitudes' (Kirzner 1997, p. 62).

The foregoing suggests that information asymmetry plays a dual role as it raises transaction costs and generates market failures but at the same time, creates market opportunities, providing incentives to develop innovations through the creation of new ventures. Two theoretical approaches are thus competing. The first one refers to the notion of information asymmetry as a market failure requiring specific arrangements regarding the financing of research and development (R\&D) activities, the allocation of control among stakeholders (e.g. inventors, financiers, users) or the distribution of property rights (Aghion and Tirole 1994). According to that approach, information is assimilated to a commodity that can be exchanged through market mechanisms, requiring stakeholders to negotiate for contractual arrangements that aim at minimizing transaction costs. The second approach refers to the idea of information asymmetry as a major source of market opportunities (Shane and Venkataraman 2000) and competitive advantage (Miller 2003), the latter being unveiled through a process of 'entrepreneurial discovery' (Kirzner 1997). This second view puts particular emphasis on information asymmetries resulting from differences in individuals' knowledge and cognitive abilities. Therein, asymmetrically distributed cognition is a major source of interindividual differentiation that allows certain individuals (and organisations) to create, identify and seize business opportunities.

This article elaborates on the dual character of the concept of information asymmetry regarding its impact on innovation management. It contends that a comprehensive review that examines both approaches of information asymmetry can help improve our understanding of how innovations are managed under asymmetric information. Industrial organisation theorists subtly suggested that the 'recognition of informational asymmetries and the strategic possibilities they engender can yield models that begin to capture the richness of behaviour that marks the real world' (Milgrom and Roberts 1987, p. 185, italics added). Among the strategic possibilities mentioned by Milgrom and Roberts, some are specifically concerned with the management of innovation and R\&D activities. The goal of this article was thus to build on the economics of information asymmetry to provide a more complete perspective on the relationship of asymmetric information to innovation. The literature review will focus on three streams of research in innovation management: industrial economics, financial economics and entrepreneurship. These research streams help illustrate that information asymmetries exert a direct but ambiguous influence on innovation and $R \& D$.

The rest of the article is organised as follows. It begins by discussing the concept of information asymmetry and its relationship to innovation management. Then, the article introduces methodological statements regarding how the bibliometric search has been conducted. Next, results are presented and organised in two categories. Finally, the article discusses the main implications of the review and introduces propositions to guide future research.

\section{The economics of information asymmetry and the management of innovation}

Standard microeconomics theory assumes that information sets regarding goods and services available on the market are complete and perfect. Within this framework, 'everyone knows everything' (Milgrom and Roberts 1987), p. 184, transaction costs tend 
to zero, and contracts are complete. However, empirical observations suggest that, in many cases, individuals have private information about themselves (e.g. their preferences) and their economic environment which may or may not be complete but differ from others' information sets. According to Stiglitz (2000), information asymmetries among agents alter the nature of market processes. Akerlof (1970) early indicated that informational problems are likely to interfere with market-clearing mechanisms. His classical work on 'the market for lemons' demonstrated that when buyers and sellers do not share the same information sets during a transaction, goods and services of heterogeneous quality can coexist in the marketplace. As Stiglitz (2000) argued, 'because of these $[\ldots]$ problems of information [...] the exchange process is intertwined with the process of selection over hidden characteristics and the process of providing incentives for hidden behaviors' (Stiglitz 2000, p. 1447). Under conditions of asymmetric information therefore, 'bad-quality providers can enter the market and drive out the good quality providers by so lowering price that the latter cannot obtain returns on their investments for competence enhancement' (Nayyar 1990), p. 517.

The recognition that information is imperfect, costly, asymmetrically distributed and affected by the agents' strategic behaviours 'provided explanations of economic and social phenomena that otherwise would be hard to understand' (Stiglitz 2000, p. 1441). In that view, economists discriminate between two types of information asymmetry: moral hazard and adverse selection. Guesnerie et al. (1989, p. 807) referred to the notions of 'hidden knowledge' and 'hidden actions' to identify these two sources of inefficiency in resource allocation. While moral hazard results from the inability of one individual (called the Principal in Standard Agency Theory, SAT) to monitor another individual's (called the Agent in SAT) actions, adverse selection corresponds to the inability of the principal to observe an agent's private information (Picard 1987, p. 305). Because the properties of incentive contracts 'are altered in the presence of such concerns about information management' (Lewis and Sappington 1997, p. 797), research efforts focused on designing contractual arrangements that aim at reducing the negative impacts of information asymmetries. Two broad categories of contractual agency are likely to reduce information asymmetry: (1) self-selection, in particular through information disclosure and signalling, and screening, and (2) designing of incentive structures and monitoring (Stiglitz 2000). The first category provides rational responses to adverse selection problems; the second one is likely to reduce moral hazard situations.

Many economic situations involving problems of information asymmetry have been investigated in the literature. The latter includes employers who invest time and resources in order to observe the real productivity and true abilities of their (current and future) employees or venture capitalists who want to know the return on various technologies in which they might invest. Any of these situations induce additional search costs at least for the agents who have to invest time and effort to discover the real characteristics of goods and services available on the marketplace and/or the behaviours of other agents with whom they negotiate. Although the economics of information 'has provided a new set of lenses through which a wide variety of issues can be viewed' (Stiglitz 2000, p. 1453), there is one among those issues that deserved special attention from economists: innovation management. Aghion and Tirole (1994) suggested that understanding how innovation is managed under asymmetric information requires refreshing our views on 'how to finance the research activities, how to allocate control 
over the R\&D process, how to share property rights on innovations, and how to structure the monetary compensations to the inventors' (Aghion and Tirole 1994, p. 1185). Investigating innovation management under asymmetric information opens up new ways of theorising on 'the exact microeconomic process by which information and ideas move along the supply chain in the production of knowledge' (Martimort et al. 2010, p. 324). As Martimort et al. (2010, p. 325) explained 'commercial ideas may contain technical aspects often hard to describe contractually but privately known by innovators'. Therefore, stakeholders involved in the management of innovation (including innovators, financiers and users) must find way to design optimal contracts which provide incentives to disclose private information and hamper the negative effects of contractual hazards and opportunistic behaviours.

How do agents manage to reduce the impacts and/or harness the benefits of information asymmetries when collectively participating in the process of inventing new ideas and capturing value from their commercialisation? Next, sections investigate this question by building on a literature review that aims at providing a more complete perspective on the relationship of asymmetric information to innovation management.

\section{Methodology}

Our bibliometric search required criteria for selecting the types of articles to be included in the analysis. In addition, it needed a search strategy for collecting data, classifying them and analysing their theoretical and empirical content. Given the huge amount of researches on the economics of information asymmetry, the review is focused on articles investigating innovation management under asymmetric information. To search for appropriate literature investigating the above research question, we began by exploring two academic databases: JSTOR (Ithaka) and ScienceDirect (Elsevier) by using the following Boolean phrase: 'Asymmetric information' or 'Information asymmetry'. In order to refine the search process, we introduced the following additional keywords using the 'AND' Boolean operator: 'Innovation', 'Innovation management' and 'Entrepreneurship'. The foregoing led us to reduce the sample of articles investigating innovation and entrepreneurship under conditions of asymmetric information. Then, we scanned the bibliographies of the most recent articles to ensure that we did not miss seminal articles, limiting our investigation on those articles that have been published in the leading journals in economics and management science. We referred to the 45th edition of the Journal Quality List (JQL; Harzing 2012) to identify leading journals in financial economics, industrial organisation, entrepreneurship and innovation management (e.g. The American Economic Review, Administrative Science Quarterly, Management Science, The Journal of Industrial Economics, Academy of Management Review, The Journal of Finance). The method for analysis of collected data was to first discriminate articles according to their disciplinary background. Three sub-disciplines have been identified: applied microeconomics (including industrial organisation), financial economics and entrepreneurship (including the management of innovation and $R \& D)^{a}$.

Next, we investigated the content of each article. Our goal was to determine each article's main theme, theoretical background, methodology and relevant findings. Building on the foregoing classification, we identified three core topics related to the management of innovation under asymmetric information: contracting for innovations, 
financing innovations and developing innovations. The first two topics have been merely investigated by industrial and financial economists who analysed how stakeholders manage to mitigate information asymmetries either by disclosing information (signalling strategies) or negotiating efficient contracts for allocating property rights or transferring knowledge and technology. The third topic has been studied by economists (in particular those of the Austrian tradition) and organisational theorists who seek to understand how information asymmetries generate opportunities for creating new ventures and capturing value from innovations. While industrial and financial economists share the view that innovations already exist and that the core problem is about designing contractual arrangements that enable participants to 'fix' market failures rooted in information asymmetries, economists and organisational theorists rather focus research efforts on how individuals and firms manage to discover and seize entrepreneurial opportunities that lead to invent and commercialise new ideas.

\section{The management of innovation under asymmetric information: three core issues}

The next sections discriminate between three core issues regarding the management of innovation under asymmetric information: contracting for innovation, financing innovation and developing innovation.

\section{Contracting for innovation}

Many studies dealt with the question of how information asymmetry makes the management of innovation under asymmetric information a complicated process, therefore requiring specific contractual arrangements to mitigate its effects (Crémer and Khalil 1992; Grossman and Hart 1983a; Grossman and Hart 1983b; Hart and Moore 1988; Milgrom and Roberts 1986; Milgrom and Roberts 1987; Sappington 1982; Sappington 1991).

Within this framework, scholars studied how information asymmetries influence the contractual arrangements set up by innovation stakeholders when meeting innovationrelated challenges, including value capturing, knowledge sharing, technology transfer, organisation design of R\&D and the diffusion of innovations.

To investigate these topics, scholars elaborated on specific theoretical tools, essentially standard agency theory (SAT), incomplete contract theory and game theory. Within this framework, one of the core hypothesis made by industrial (and financial economists) is that strategic disclosure of private information is likely to mitigate the effects of information asymmetries (Stiglitz and Weiss 1981; Bhattacharya and Ritter 1983). Signalling is thus considered as an efficient behaviour when confronting adverse selection issues (Spence 2002). However, as Lewis (2011) argued, whether information disclosure through signalling strategies reduces information asymmetries depends on two parameters: the costs associated to private information disclosure and the presence of some institutional framework allowing contractual enforcement. Anton and Yao (2004), for example, indicated that when property rights are weak, disclosure incentives are relatively stronger, in particular for nondrastic (e.g. incremental) innovations. It follows that secrecy (i.e. no disclosure at all) is considered by the firm as a better response in order to protect drastic (e.g. radical) innovations from imitation and harness the full benefit of their commercialisation. In the same vein, Jansen (2010) argued that incentives to strategically disclose information depend on the trade-off between two effects: business stealing and free riding that come from information asymmetries. The 
business stealing effect emerges when firms, while competing for an innovation where winner takes all, over-invest in $R \& D$. The free rider effect appears when the winner firm of an $R \& D$ race is not capable of appropriating the full revenue of its innovation, because the later generates positive externalities (see Jansen 2010, p. 350). In this framework, the disclosure strategy is affected by the nature of the legal environment governing appropriation issues, the latter determining the spill-over value (i.e. strong versus weak externalities) attached to the innovation. It follows that information disclosure is also dependent upon the type of innovation at stake, the latter being determinative for the allocation of property rights among agents (Aghion and Tirole 1994) and the selection of the fittest appropriation regime for capturing and sharing the value generated by the commercialisation of innovations. Besides legal issues, the inventor is also affected by its initial financial resources when dealing with appropriation of innovation value. Anton and Yao (1994) indicated that an inventor with limited initial resources is likely to capture a sizeable share of the market value of the innovation by revealing its invention before starting negotiations (ex post contracting). It follows that with larger financial resources (e.g. from venture capitalists), an inventor prefers $e x$ ante contracting, in which parties try to mitigate information asymmetries by employing an appropriately structured ex ante contract. In a later article, Anton and Yao (2002) further indicated that when inventors are wealth constrained, rent appropriation through market sale is lower and this might cause (1) an inventor to go to market earlier and/or (2) an inventor to connect to a financial intermediary to obtain additional funds prior to taking invention to customers.

In line with the previous research streams, it has been demonstrated that knowledge sharing is facilitated when there exists a legal environment that frames the agents' knowledge exchanges by protecting the innovators' investments. Exploring optimal contracting within a two-stage R\&D joint venture, Bhattacharya et al. (1990) explained that knowledge sharing among firms is made easier when it is possible to sign agreements that specify how the gains from success will be divided among parties. Ex ante agreements to share revenue from innovation are likely to reduce competitive pressure between the firms and 'restore incentives for sharing knowledge' (Bhattacharya et al. 1990), p. 204. It follows that by designing license contracts with patented innovations, firms are more capable of managing knowledge sharing and technology transfer issues. Investigating licensing contracts' agreements between firms that aim at transferring protected innovations, Gallini and Wright (1990) explained that the latter respond to two information asymmetry problems: (1) the superiority of a licensor's information on the value of the innovation and (2) the ability of licensees to 'invent around' the transferred innovation. Within this framework, output royalties, rent sharing between the licensor and the licensee(s), and exclusive versus nonexclusive licenses represent the various options available to the firms that seek to cooperate in order to exploit innovations. Gallini and Wright (1990) discriminate between two types of innovation: low-value (low-cost) and high-value (high-cost) innovations. Then, the authors demonstrated that low-cost innovations 'can be fully exploited with an exclusive contract and a fixed fee' (Gallini and Wright 1990, p. 157), while high-cost innovations require (1) exclusive contracts with nonlinear royalties in output when the innovation is drastic (nonexclusive contracts when the innovation is nondrastic), (2) rent sharing contacts when imitation costs are low and/or there exists large rent differential between drastic 
and nondrastic innovations, and (3) both exclusive and nonexclusive contracts when innovation is drastic and imitation costs are large. In another article, Gallini and Winter (1985, p. 238) already assumed that incentives to invest in R\&D under licensing agreements depend on the firms' production costs; when the latter differs, licensing discourages research, while it is encouraged when firms exhibit close production costs. Adopting a game theoretic approach of agency problems, Anton and Yao (1995) explored the specific question of organisation design of R\&D when invention emerges within the firm (the principal) thanks to the creative work of one of its employee (the agent). Fundamentally, the organisational option adopted shall have a direct impact on the allocation of property rights and the way innovations' value is captured and distributed among agents. In the situation that Anton and Yao (1995) investigated, both the firm and the employee are facing a trade-off between various organisational options: creating a start-up, introducing a spin-off company or internalising the innovation project. The authors argued that the start-up option is likely to be implemented depending on (1) the employee's ease of access to financial resources relative to the value of invention, (2) the expected profits of a monopoly with a start-up when compared with the expected profits of a monopoly under a spin-off and (3) the symmetric versus asymmetric distribution of the bargaining power between the firm and its employees.

Adopting a different theoretical perspective, Riordan and Sappington (1987) modelled a two-step production process with privately informed agents in order to examine how information asymmetries regarding realisation costs at each step influence the choice of the fittest organisational mode. Organisation design options available to the entrepreneur (the principal) include partial delegation versus complete delegation of some task to a specialised firm (the agent). Riordan and Sappington (1987, p. 244) suggested that the selection of a particular organisation design by the principal depends upon (1) the level of dependency of cost realisations, (2) the negative or positive nature of the correlation between cost realisations and (3) the degree (large versus small) of (negative) correlation. Investigating the question of organising $R \& D$ activities in a principal-agent framework, Aghion and Tirole (1994) suggested that integrated organisational forms in which the agent (a customer) owns and freely uses the innovation provided by the principal (a research unit) are likely to fit situations exhibiting (1) a capitalintensive innovation environment, (2) asymmetric bargaining powers benefiting to the agent (customer) over the principal (research unit) and (3) a customer that does not suffer from financial constraints. When the situation does not show evidence of those three conditions, it may be optimal for a customer to give property rights to the research unit and to demand additional financial resources from an external investor.

Connected to technological transfer and organisation design issues is the one concerned with the adoption and/or diffusion of innovations. Indeed, following Lapan and Moschini (2000, p. 525), 'it is not the mere discovery of new knowledge that leads to economic progress: to realize private and/or social benefits it is necessary for an innovation to be adopted by firms'. It follows that when an innovation is not adopted directly by the innovator, it has to be transferred to other firms, for example, through licensing agreements. Bhattacharya et al. (1986) proposed an empirically plausible theory of the diffusion of innovations when innovation payoffs' distributions are unknown. Reproducing some stylized facts related to the rate and speed of diffusion, and the 
cumulative proportion of adopters, the authors demonstrated that the diffusion of innovations is not dependent upon variations in firms' priors regarding the (ex ante unknown) performance of an innovation. Rather, random differences in observed samples are sufficient to yield diffusion curve matching the commonly observed empirical regularities in diffusion (Bhattacharya et al. 1986, p. 220). In the same vein, Quirmbach (1986, p. 42) indicated that the diffusion of a new technology is not caused by external shocks or user firms' information asymmetries but results from 'declining incremental benefits and adoption costs'. Diffusion is thus the outcome of asymmetries not among players' information sets but in the payoffs' distributions.

\section{Financing innovation}

Within the context of capital markets for R\&D, information asymmetry between entrepreneurs and investors creates market failures (e.g. credit rationing) that call for efficient contractual arrangements to mitigate its negative effects. Within the capital market, the sources of information asymmetries are diverse. As Aboody and Lev (2000, p. 2750) argued, 'the uniqueness of R\&D investments makes it difficult for outsiders to learn about the productivity and value of a given firm's $R \& D$ from the performance and products of other firms, thereby contributing to information asymmetry'. In addition, it has been demonstrated that 'market players in closer touch with a firm and its business (...) are those who possess better information about that firm' (Barath et al. 2009, p. 3215). Stiglitz and Weiss (1981) examined the credit rationing phenomena in the capital markets as merely caused by asymmetric information among capital suppliers and borrowers. The authors explained that banks may prefer to reject some borrowers because of negative adverse selection and incentive effects; for a given collateral, an increase in the rate of interest causes adverse selection, since only borrowers with riskier investments will apply for a loan at a higher interest rate. Similarly, higher interest payments create an incentive for investors to choose projects with a higher probability of bankruptcy. Extending the work of Stiglitz and Weiss (1981), Bester (1985) further suggested that no credit rationing will occur if banks compete by choosing simultaneously collateral requirements and the rate of interest, the latter enabling them to screen investors' risk profiles and eliminate the riskiest.

Investigating less traditional financial organisations' investment strategies, Trester (1998) demonstrated that venture capitalists use equity (i.e. preferred equity) rather than debt to finance entrepreneurial projects because this contract eliminates the foreclose option which is known to be a source of opportunistic behaviours. Indeed, entrepreneurs benefiting from superior information about the innovation profitability might be tempted to take project payoffs and defaulting on the debt, when the parties adopted such a contract. Audretsch et al. (2012) indicated that venture capitalists are likely to mitigate the negative effects of information asymmetry (e.g. opportunistic behaviours) by privileging innovative firms when they combine appropriability signals (i.e. patents and patents' applications) with feasibility information (i.e. prototypes). Another strategy for financial institutions to discover the true performance of entrepreneurs' project is to observe whether or not the latter receives financial support from public organisations. Takalo and Tanayama (2010) pointed out that if a project received a public subsidy from a public agency, it provides a signal about the quality of the R\&D project. Such a subsidy-observation increases the success probability of the project anticipated 
by the market-based financier. This, in turn, alleviates financing constraints by reducing the cost of external capital for subsidised projects.

Complementing financial institutions' (i.e. principals) efforts to mitigate the negative effects of asymmetric information, the voluntary disclosure of private information by innovative firms (i.e. agents) is also likely to facilitate investment contracts' arrangements. Building on a literature review of empirical corporate disclosure strategies as observed in capital markets, Healy and Pelepu (2001) indicated that voluntary disclosure of corporate information, including internal reports and financial analysts' and auditors' reports, helps mitigate information asymmetries (and agency problems). Disclosure is also associated with stock price performance, bid-ask spreads, analysts' following and institutional ownership. Ang and Cheng (2011) suggested that firms that need external financing choose and maintain a higher level of communication with the market, the latter being associated with a higher probability of equity issuance. The authors further indicated that depending on the firms' financial constraints, communication channels shall differ; public communication channels are more likely to be adopted by firms with little cash, while communication through interactions with analysts is a preferred option for high-growth firms.

Although the voluntary disclosure of private information is likely to generate positive outcomes in facilitating the negotiation of contractual arrangements, it has also been shown that inventors may be reluctant to fully disclose private information to potential investors because they fear opportunistic behaviours and imitation. Discussing the financing of new ventures under asymmetric information between entrepreneurs and financiers, Shane and Cable (2002) considered that the explanations provided by economists (e.g. self-selection through signalling, the allocation of property rights or the staging of capital) are incomplete for at least two reasons. 'First, the over optimism of entrepreneurs (...) undermines the effectiveness of the contractual mechanisms described by economists' (Shane and Cable 2002, p. 366), making self-selection ineffective. The argument brought by the authors is that early-stage investors cannot shift all the risk of investing in a new venture to entrepreneurs and 'must make investments that risk the total loss of their capital' (Shane and Cable 2002, p. 366). In addition, information disclosure through patenting for example can not lead outsiders (i.e. venture capitalists) to gain all the private information they need. As Kyles (1985, p. 1326) argued, although insiders' information get progressively incorporated into market signals through information disclosure, 'not all information is incorporated into prices'.

\section{Developing innovation}

As Shane (2000, p. 451) authoritatively declared that 'opportunities exist because different people possess different information'. An opportunity denotes a favourable circumstance or combination of circumstances raising a promising state of affairs within particular conditions of time and space. Ardichvili et al. (2003, p. 108) defined an opportunity as 'a chance to meet a market need (...) through a creative combination of resources to deliver superior value'. Shane and Venkataraman (2000, p. 220) further suggested that entrepreneurial opportunities 'are those situations in which new goods, services, raw materials, and organising methods can be introduced and sold at greater than their cost of production'. In its most elemental form, an opportunity describes 'a phenomena that begin unformed and become more developed through time' 
(Ardichvili et al. 2003, p. 108) thanks to the entrepreneurial efforts made by an individual or a group of individuals. As a result, opportunities (1) are likely to be limited in time, (2) need to be discovered and (3) sized through some entrepreneurial agency (Kirzner 1997).

Exploring the role played by market imperfections (e.g. externalities, flawed pricing mechanisms, inefficient firms and asymmetric information) in generating opportunities within markets for sustainable goods and services, Cohen and Winn (2007) acknowledged that asymmetrically distributed information create conditions for opportunities to emerge. The authors further contended that 'the poorer the information is, the greater the number and scope of entrepreneurial opportunities' (Cohen and Winn 2007, p. 44). The foregoing suggests that information gaps are a powerful engine of innovation since they constitute major sources of opportunities. Indeed, the discovery and exploitation of (valuable) opportunities are likely to generate entrepreneurial profits (Eckhardt and Shane 2003). Since entrepreneurs hold information about what they know and do outsiders do not possess, scholars indicated that they can earn rents by exploiting information asymmetries, the latter being considered as a source of monopoly power. Davis (2001) contended that rents can be obtained by combining four information-oriented strategies: '(1) publish the details of the innovation in return for legal protection (patents, copyrights and the like), (2) keep the information inside the firm (secrecy, tacit and firm specific knowledge), (3) make the information selectively available to others on an informal basis and (4) widely disseminate the information making it freely accessible to all comers' (Davis 2001, p. 327). In doing so, firms seek to control how information about the characteristics of their innovations get revealed to the market (disclosure strategies) in order to confront potential competition (through imitation for example) and ensure sustainable profitability.

The above discussion of the role played by asymmetric information in the origination of economic opportunities is in line with the Austrian theory of competition as a discovery procedure. Kirzner (1997), p.73 indicated that 'competition that characterizes the market process reveals information which no one was aware of its having been lacking'. Therein, entrepreneurship is the driving force that leads individuals 'pushing back the boundaries of sheer ignorance [...] increasing mutual awareness among market participants and thus, in turn, driving prices, output and input quantities and qualities, toward values consistent with equilibrium' (Kirzner 1997, p. 62). In other words, entrepreneurship - considered as a discovery process - is likely to mitigate the negative effects generated by information asymmetries on the allocation of scarce resources, therefore transforming market failures into market opportunities. This does not mean that individuals sharing identical information sets shall equally be capable of recognising all opportunities.

Indeed, individuals differ according to their prior knowledge, the latter being determinative for their ability to detect and make sense of information. While opportunities exist objectively, their recognition remains heavily dependent upon the individuals' abilities (Amit et al. 1990). Adopting an industrial economics perspective, Crémer and Khalil (1992, p. 566) suggested that 'in reality [...] the fundamental asymmetry lies in the ability to acquire information, not simply in the characters attached to information itself (see also Tirole 2009 for a cognitive view on incomplete contract theory). It results that opportunities can not result from a rational search procedure but requires 
forming expectations about unknown economic data (Eckhardt and Shane 2003) through the cognitive process of mental recognition. Within this framework, Shane (2000, p. 452) suggested that 'three major dimensions of prior knowledge are important to the process of entrepreneurial discovery: prior knowledge of markets, prior knowledge of ways to serve markets, and prior knowledge of customer problems'. As such, prior knowledge accumulated through experience provides agents with idiosyncratic resources which, in turn, can be a potent source of competitive advantage when applied to discover and exploit entrepreneurial opportunities (Nayyar 1990). Miller (2003) introduced a three-step model that exemplifies how firms (not limited to service providers) convert asymmetries into resources enabling them to benefit from competitive advantage. The author demonstrated that building capabilities out of asymmetries involves that the firm is capable of doing 'three things well:

1. Discover the asymmetries (...) and discern the potential between them.

2. Turn asymmetries into capabilities by strategically embedding them within an organizational design configuration that exploits them and sustains their development.

3. Match asymmetry-derived capabilities to market opportunities' (Miller 2003), p. 965.

Therein, the identification and selection of valuable asymmetries require both internally and externally oriented processes, including experimentation, incremental learning, organizational introspection, reflective inquiry and search for weaknesses, and bootstrapping on emerging capabilities (Miller 2003, p. 965-968). Within this framework, firms build their competitive advantage not on resources and capabilities as the resource-based view (RBV) suggests but on asymmetries in skills, processes and a variety of tangible and intangible assets (including cultural values) which their competitors cannot copy and/or absorb at a cost that afford economic rents.

\section{Results and discussion}

The development of information economics has had a profound impact on economic theory. By attempting to 'capture informational aspects of market structure', industrial economists enlarged our knowledge of 'the ways in which markets adapt, and the consequences of informational gaps for market performance' (Spence 2002, p. 435). Because information is imperfect and costly to gather and interpret, 'demand could differ from supply in equilibrium' (Stiglitz 2000, p. 1460). This information revolution irrigated many different fields, including applied microeconomics, financial economics, labour market theory and the theory of the firm. It also triggered the development of original modelling techniques, including asymmetric information game theory and standard agency theory (SAT). Within this framework, designing and writing contracts between parties that hold different information sets and cognitive abilities became a central question, in particular when parties negotiate for the exchange of new goods and services. The allocation of property rights, the organisational design of R\&D activities, the financing of the various phases of the innovation process and the sharing of productive knowledge all raised research questions that called for theoretical and empirical investigations. However, some scholars consider that the explanations provided by industrial and financial economists regarding how agents overcome information asymmetries do not draw on the full implications of the existence of 
asymmetries among the agents' beliefs, abilities and information (Kirzner 1997). Fundamentally, these scholars consider that asymmetries represent an essential source of disequilibrium within and across markets, the latter generating entrepreneurial opportunities (Shane 2000) that individuals, depending on their own knowledge and abilities, recognise, evaluate and develop further. The foregoing involves going beyond the study of rational strategies (e.g. signalling, screening, monitoring) enabling individuals to negotiate contracts which mitigate the negative effects of asymmetric information, to focus research efforts on the role played by intangible, socio-cognitive assets individuals exploit when evaluating and developing opportunities. In addition, the study of information asymmetry as a source of opportunities requires elaborating on theories and methodological tools that differ from contractual approaches (Eckhardt and Shane 2003). As an illustration, contrasting financial economics perspectives, some organisational theorists proposed that potential investors rely on social capital assets to select which ventures to fund when information is asymmetrically distributed among agents. Shane and Cable (2002, p. 366) contended that 'social obligations between connected parties, and information transfer through social relationships, influence venture finance decisions'. Therein, consistent with a self-interested approach to the investors' behaviour, social ties enable investors to obtain private information about the ventures to fund and their potential opportunities. In addition, direct and indirect ties 'create social obligations between the parties, which cause them to behave generously towards each other' (Shane and Cable 2002, p. 370). By referring to these two complementary mechanisms, the authors underlined the role played by the entrepreneurs' social capital (e.g. reputation) in providing investors with additional information about his or her capacity of implementing, managing and developing the venture. In the same vein, scholars reported many examples of successful innovative companies that find ways to harness the benefits of information asymmetries by participating in collaborative networks. Within networks, the firm must confront the challenge of selecting the 'right' research partner based on its private information about the quality of the scientific knowledge available on the market and its cost. Here again, information asymmetries make it difficult for private companies to discriminate between the variety of offers, and the selection of partners is guided by socio-organisational factors. In particular, 'geographic and social proximity (...) should play a determining role in the choice of research partner' (Abramo et al. 2011, p. 85). Social capital, direct and indirect ties and reputation effects are likely to guide the firm in identifying promising research partners if information about their quality is lacking. Tödling et al. (2009) supported this assertion indicating that collaborative innovation that draws on new scientific knowledge requires personal interactions among innovation stakeholders. The development of collaborative innovation enables stakeholders to interact, communicate and share knowledge through formal (e.g. licensing, spin-offs) as well as informal (e.g. socio-cultural proximity, personal linkages) relationships.

The above discussion exemplifies how contractual and entrepreneurial approaches of innovation could combine to improve our understanding of how innovations are managed under information and knowledge asymmetries. We suggest that the reconciliation of these two views of the role played by information asymmetries requires decomposing the management of innovation into two distinct but coordinated phases. The first phase refers to the invention phase of the innovation process. It is concerned 
with the generation, evaluation and initial development of new ideas. These particular activities correspond to three sequences of the innovation process involving specific organisational and technological challenges which cannot be reduced to contractual arrangement issues. Since the theory of entrepreneurship as a discovery process aims at detecting, formulating and elaborating on opportunities, it offers conceptual and methodological frameworks that fit with the challenges of exploring each sequence separately and understanding the way they connect to each other. The second phase, referring to the commercialisation phase, is concerned with the market-oriented and appropriation sequences. The latter suppose that innovations, whatever their types (e.g. drastic versus non drastic, goods versus service, technology versus organisation), already exist. Therein, industrial and financial economics provide useful theoretical and empirical tools to investigate how stakeholders involved in innovation projects manage to capture and distribute the value generated by bringing new ideas to the marketplace. The foregoing suggests a natural division of labour between the two approaches of innovation: while the theory of entrepreneurship as a discovery procedure develops useful insights into the upstream sequences of the innovation process (e.g. invention), industrial economics provides consistent modelling techniques for dealing with downstream sequences of contracting for and financing innovation (e.g. commercialisation). Rather than introducing conflicting perspectives on innovation, we contend they provide complementary views on critical phases of the innovation process.

\section{Conclusions}

This article focused on the role played by asymmetric information in the management of innovation. Building on a literature review, it observed that information asymmetry plays a dual role as it constitutes both a major source of market failures and a condition for entrepreneurial opportunities to exist. The idea that a single phenomenon can be considered as a failure and an opportunity is fascinating. While industrial and financial economists indicate that asymmetric information is likely to trigger opportunistic behaviours, Austrian economists and entrepreneurship theorists maintain that it provides agents with incentives to develop new ventures. Are asymmetries sources of additional transaction costs and opportunistic behaviours? Or do they identify with critical conditions for entrepreneurial and profitable opportunities? We finally argued that the reconciliation of the contractual and entrepreneurial views of the information asymmetries could deepen our understanding of the various phases that make up innovations. Hence, we assumed that the sequences through which ideas are generated, evaluated and developed (invention phase) respond to different logics and involve different capabilities than market-oriented sequences of commercialisation of ideas and appropriation of the value generated (commercialisation phase).

We hope that the assumption put forward in this article would encourage further research into the management of innovation as a decomposable process made up with distinctive sequences, each referring to specific phases of generation, evaluation, development, commercialisation and appropriation of information and knowledge-based opportunities.

\section{Endnotes}

a. It should be noted that our bibliometric search strategy led to focus on mainstream researches in the economics of information and innovation. Consequently, a large part 
of the applied literature on such issues as technological change and innovation policy has been left aside, including articles that have been published in such renowned journals as The Journal of Economic Behavior and Organization or Research Policy. We acknowledge that these journals do often publish articles that examine the role played by information asymmetry in a variety of economic contexts. However, we also obcsserve that when these articles specifically investigate how information asymmetries affect innovation management, the adopted theoretical framework, references and methodology are very often identical to those published by mainstream economics journals. In addition, enlarging our bibliometric search strategy to include such keywords as 'technological change,' 'knowledge' or 'innovation policy' would have make the number of references artificially exploded, thus making the literature review intractable.

\section{Competing interests}

The author declares that he has no competing interests.

Received: 11 September 2013 Accepted: 4 October 2013

Published: 14 Jan 2014

\section{References}

Aboody, D, \& Lev, B. (2000). Information asymmetry, R\&D, and insider gains. The Journal of Finance, LV(6), 2748-2766.

Abramo, G, D'Angelo, CA, Di Costa, F, \& Solazzi, M. (2011). The role of information asymmetry in the market for university-industry research collaboration. J Technol Transfer, 36, 84-100.

Aghion, P, \& Tirole, J. (1994). The management of innovation. The Quarterly Journal of Economics, 109(4), 1185-1209.

Akerlof, G. (1970). The market for 'Lemmons': Quality uncertainty and the market machanism. The Quarterly Journal of Economics, 84(3), 488-500.

Amit, R, Glosten, L, \& Muller, E. (1990). Entrepreneurial ability, venture investments, and risk sharing. Manag Sci, 36(10), $1232-1245$.

Ang, J, \& Cheng, Y. (2011). The endogeneity of information asymmetry and corporate financing decisions. The Journal of Financial Research, XXXIV(3), 441-440.

Anton, J, \& Yao, DA. (1994). Expropriation and inventions: appropriable rents in the absence of property rights. Am Econ Rev, 84(1), 190-209.

Anton, J, \& Yao, DA. (1995). Start-ups, spin-offs, and internal projects. Journal of Law, Economics \& Organization, 11(2), 362-378.

Anton, J, \& Yao, DA. (2002). The sale of ideas: strategic disclosure, property rights, and contracting. Rev Econ Stud, 69(3), 513-531.

Anton, J, \& Yao, DA. (2004). Little patents and big secrets: managing intellectual property. RAND J Econ, 35(1), 1-22.

Ardichvili, A, Cardozo, R, \& Ray, S. (2003). A theory of entrepreneurial opportunity identification and development. J Bus Ventur, 18, 105-123.

Audretsch, DB, Bönte, W, \& Mahagaonkar, P. (2012). Financial signalling by innovative nascent ventures: the relevance of patents and prototypes. Res Policy, 41, 1407-1421.

Barath, TS, \& Pasquariello, P. (2009). Does asymmetric information drive financial structure decisions? The Review of Financial Studies, 22(8), 3211-3243.

Bester, H. (1985). Screening vs. rationing in credit markets with imperfect information. Am Econ Rev, 75(4), 850-855.

Bhattacharya, S, \& Ritter, JR. (1983). Innovation and communication: signalling with partial disclosure. Rev Econ Stud, 50 (2), 331-346.

Bhattacharya, S, Chatterjee, K, \& Samuelson, L. (1986). Sequential Research and the Adoption of Innovations (38th ed., pp. 219-243). Oxford: Oxford Economic Papers.

Bhattacharya, S, Glazer, J, \& Sappington, DEM. (1990). Sharing productive knowledge in internally financed R\&D contests. J Ind Econ, 39(2), 187-208.

Cohen, B, \& Winn, Ml. (2007). Market imperfections, opportunity and sustainable entrepreneurship. J Bus Ventur, 22, 2949.

Crémer, J, \& Khalil, F. (1992). Gathering information before signing a contract. Am Econ Rev, 82(3), 566-578.

Davis, L. (2001). R\&D investments, information and strategy. Technology Analysis \& Strategic Management, 13(3), 325-342.

Eckhardt, JT, \& Shane, SA. (2003). Opportunities and entrepreneurship. J Manag, 29(3), 333-349.

Gallini, NT, \& Winter, RA. (1985). Licensing in the theory of innovation. RAND J Econ, 16(2), 237-252.

Gallini, NT, \& Wright, BD. (1990). Technology transfer under asymmetric information. RAND J Econ, 21(1), 147-160.

Grossman, SJ, \& Hart, OD. (1983a). An analysis of the principal-agent problem. Econometrica, 51(1), 7-45.

Grossman, SJ, \& Hart, OD. (1983b). Implicit contracts under asymmetric information. The Quarterly Journal of Economics, 90, 123-156.

Guesnerie, R, Picard, P, \& Rey, P. (1989). Adverse selection and moral hazard with risk neutral agents. European Economic Review, 33(4), 807-823.

Hart, OD, \& Moore, J. (1988). Incomplete contracts and renegotiation. Econometrica, 56(4), 755-785.

Harzing, A. (2012). Journal Quality List. Available at http://www.harzing.com/jql.html.

Healy, PM, \& Pelepu, KG. (2001). Information asymmetry, corporate disclosure, and the capital markets: a review of the empirical literature disclosure literature. J Account Econ, 31, 405-440. 
Jansen, J. (2010). Strategic information disclosure and competition for an imperfectly protected innovation. The Journal of Industrial Economics, LVIII, 2, 349-372.

Kirzner, I. (1997). Entrepreneurial discovery and the competitive market process: an Austrian approach. J Econ Perspect, $35(1), 60-85$.

Kyles, A. (1985). Continuous auctions and insider trading. Econometrica, 6, 1315-1335.

Lapan, HE, \& Moschini, G. (2000). Incomplete adoption of a superior innovation. Economica, 67(268), 525-542.

Lewis, G. (2011). Asymmetric information, adverse selection and online disclosure: the case of eBay motors. Am Econ Rev, 101, 1535-1546.

Lewis, TR, \& Sappington, DEM. (1997). Information management in incentive problems. J Polit Econ, 105(4), 796-821.

Martimort, D, Poudou, J-C, \& Sand-Zantman, W. (2010). Contracting for an innovation under bilateral asymmetric information. J Ind Econ, LVIII(2), 324-348.

Milgrom, P, \& Roberts, J. (1986). Relying on the information of interested parties. RAND J Econ, 17(1), 18-32.

Milgrom, P, \& Roberts, J. (1987). Informational asymmetries, strategic behavior, and industrial organization. Am Econ Rev, 77(2), 184-193.

Miller, D. (2003). An asymmetry-based view of advantage: towards an attainable sustainability. Strateg Manag J, 24(10), 961-976.

Nayyar, PR. (1990). Information asymmetries: a source of competitive advantage for diversified service firms. Strateg Manag J, 11(7), 513-519.

Picard, P. (1987). On the design of incentive schemes under moral hazard and adverse selection. Journal of Public Economics, 33(3), 305-331.

Quirmbach, HC. (1986). The diffusion of new technology and the market for an innovation. RAND J Econ, 17(1), 33-47.

Riordan, MH, \& Sappington, DEM. (1987). Information, incentives, and organizational mode. The Quarterly Journal of Economics, 102(2), 243-264.

Sappington, DEM. (1982). Optimal regulation of research and development under imperfect information. The Bell Journal of Economics, 13(2), 354-369.

Sappington, DEM. (1991). Incentives in principal-agent relationships. J Econ Perspect, 5(2), 45-66.

Shane, S. (2000). Prior knowledge and the discovery of entrepreneurial opportunities. Organ Sci, 11(4), 448-469.

Shane, S, \& Cable, D. (2002). Network ties, reputation, and the financing of new ventures. Manag Sci, 48(3), 364-381.

Shane, S, \& Venkataraman, S. (2000). The promise of entrepreneurship as a field of research. Acad Manag Rev, 25(1), $217-226$.

Spence, M. (1976). Informational aspects of market structure: an introduction. The Quarterly Journal of Economics, 90(4), $591-97$.

Spence, M. (2002). Signaling in retrospect and the informational structure of markets. Am Econ Rev, 92(3), 434-459.

Stiglitz, J. (2000). The contributions of the economics of information to twentieth century economics. The Quarterly Journal of Economics, 115(4), 1441-1478.

Stiglitz, JE, \& Weiss, A. (1981). Credit rationing in markets with imperfect information. The American Economic Review, 71 (3), 393-410.

Takalo, T, \& Tanayama, T. (2010). Adverse selection and financing of innovation: is there a need for R\&D subsidies? J Technol Transfer, 35, 16-41.

Tirole, J. (2009). Cognition and incomplete contracts. Am Econ Rev, 99(1), 265-294.

Tödling, F, Lehner, P, \& Kaufmann, A. (2009). Do different types of innovation rely on specific kinds of knowledge interactions? Technovation, 29(1), 59-71.

Trester, JJ. (1998). Venture capital contracting under asymmetric information. J Bank Financ, 22, 675-699.

10.1186/2192-5372-3-5

Cite this article as: Barbaroux: From market failures to market opportunities: managing innovation under asymmetric information. Journal of Innovation and Entrepreneurship 2014, 3:5

\section{Submit your manuscript to a SpringerOpen ${ }^{\circ}$ journal and benefit from:}

- Convenient online submission

- Rigorous peer review

- Immediate publication on acceptance

- Open access: articles freely available online

- High visibility within the field

Retaining the copyright to your article

Submit your next manuscript at $\gg$ springeropen.com 